\title{
Constructing identities: the implications of DTC ancestry testing for tribal communities
}

\author{
Hina Walajahi, BS ${ }^{1}$, David R. Wilson, $\mathrm{PhD}^{2}$ and Sara Chandros Hull, $\mathrm{PhD}^{1,3}$
}

Purpose: Direct-to-consumer (DTC) genetic ancestry companies have rapidly increased in popularity, with top testing services maintaining genetic databases of several million consumers. While genetic ancestry tests are often characterized as recreational, companies invoke deeply personal concepts of individual identity, group membership, and kinship when marketing their services. In particular, many companies claim to be able to determine Native American heritage, claims that are not supported by the state of the science and may have significant cultural and political consequences for US tribal communities. This study aims to fill the gaps in empirical work on this issue and characterize how genetic ancestry companies articulate indigenous identity through their marketing strategies.

Methods: We conducted a qualitative content analysis of the public facing websites for 25 DTC genetic ancestry companies that offer services measuring Native American ancestry.
Results: Our findings describe how genetic ancestry companies promote a causal relationship between genetics and self-identity through marketing language such as "Discover Yourself" and "Are you Native American?" and how this may affect US tribal communities.

Conclusion: Genetic ancestry company claims regarding genetic ancestry, personal identity, and cultural membership are problematic and challenge how US tribal nations currently identify and create potential obstacles for tribal sovereignty.

Genetics in Medicine (2019) 21:1744-1750; https://doi.org/10.1038/s41436018-0429-2

Keywords: indigenous identity; direct-to-consumer; commercial ancestry test; Native American; empirical bioethics

\section{INTRODUCTION}

Direct-to-consumer (DTC) genetic ancestry companies have exploded in popularity within the past few years, with the top testing services maintaining genetic databases of several million customers. ${ }^{1,2}$ The rise of this industry, as with many commercial iterations of biotechnology, has attracted extensive scrutiny from scholars and policymakers regarding company promises and practices around the storage and use of consumer genetic data. ${ }^{3}$ Concerns surrounding DTC genetic ancestry companies have primarily focused on the conclusiveness of the science, ${ }^{4-6}$ the transparency of the methods of analysis, ${ }^{6,7}$ policies on consumer privacy and data protection, ${ }^{8,9}$ and whether there is adequate regulatory oversight to ensure quality and validity of testing results. ${ }^{7,10,11}$ More companies are participating in genetics research, both on their own and in partnership with external research institutions, raising questions about the nature of consent, collection and distribution of genetic data, and appropriate research oversight. ${ }^{2}$

Scholars have also commented on the broader potential of DTC genetic ancestry testing to conflate genetics with socially constructed concepts of race, an argument of relevance to ongoing debates regarding loosely defined and interchangeable uses of race and ethnicity in genetics research. ${ }^{12-14}$ Drawing correlates between genetics and socially defined categories can propagate genetic deterministic beliefs (i.e., the notion that race and/or ethnicity is genetically determined), and reify current racial groups. This has the potential to justify race-based discrimination on the basis of "inherent" genetic differences and further marginalize populations of color. ${ }^{12}$ Another concern considers how genetic ancestry companies relate genetics to political and cultural identities, ${ }^{15}$ which has consequences for structures of governance, political membership, and access to political and cultural entitlements such as federal services. These issues are exemplified in a class-action lawsuit launched in 2002 by reparations lawyer Deadria Farmer-Paellmanna, along with descendants of slaves, that sought monetary reparations from industries that demonstrated a long history of benefitting from slavery. Farmer-Paellmanna used DNA ancestry tests to prove that the plaintiffs could trace their ancestry back to African slaves. ${ }^{16}$

${ }^{1}$ Department of Bioethics, Clinical Center, National Institutes of Health, Bethesda, MD, USA; ${ }^{2}$ Tribal Health Research Office, Office of the Director, National Institutes of Health, Bethesda, MD, USA; ${ }^{3}$ Bioethics Core, National Human Genome Research Institute, National Institutes of Health, Bethesda, MD, USA. Correspondence: Sara Chandros Hull (shull@mail.nih.gov) 
Although the case was ultimately dismissed, it illustrates how genetic ancestry interacts with cultural claims and memberships. Previous scholarship has already elaborated on how genetic ancestry has impacted consumer behavior, specifically how individuals personally identify and interpret their family histories, ${ }^{17-19}$ determine their political identity, ${ }^{15}$ and seek/justify membership in communities. ${ }^{18,20}$

Members of US tribal communities have raised concerns regarding the marketing and use of genetic ancestry tests as evidence in tribal enrollment decisions. ${ }^{21}$ These concerns are layered on a backdrop of already fraught relationships between genetics researchers and tribal communities. ${ }^{22}$ Media reports have described cases where DNA tests were suggested or used to "validate" one's Native American heritage without considering the complex social, political, and historical narratives that comprise such identities. ${ }^{23}$ Similar concerns emerge around the extent to which DTC genetic ancestry companies propagate a reductionist interpretation of tribal identity, relying on cultural stereotypes when characterizing Native American ancestry in marketing campaigns. One notable advertisement posted on YouTube by AncestryDNA depicts a customer describing her surprise at discovering a quarter percentage of Native American ancestry, talking among seemingly Native artifacts intended to reflect the customer's newfound heritage. Depictions and messages such as these oversimplify both the richer concept of what it means to be Native American and a tribe's sovereign power to establish what comprises such an identity.

This paper will focus on how DTC genetic ancestry companies reconstruct cultural and political identities using genetic tools, specifically looking at Native American ancestry claims. It will concentrate on the unique context of US tribes, examining how genetic ancestry tests interact with the federal recognition system for tribes and the individual tribal enrollment process. The extent to which companies make claims about Native American identity through genetic ancestry testing has been scarcely documented, let alone empirically analyzed. This paper aims to address this gap by analyzing how DTC genetic ancestry companies construct claims about the relationship between genetic ancestry and Native American identity and the possible sociopolitical ramifications for tribal communities.

(Note: Following the example of scholars who have written about Native peoples, we recognize that "Native American" is not universally used by tribes to identify themselves. We employ the term with the intention of describing a multiethnic community characterized by a shared history of erasure and rejection of its indigenous identity. Throughout the paper we will use the terms "Native American" and "tribal" to refer specifically to US tribal communities.)

\section{MATERIALS AND METHODS}

We compiled a list of DTC ancestry companies previously aggregated in scholarly literature $\mathrm{s}^{5,10,24}$ and recorded 42 unique companies that offered a DNA ancestry test. To account for the volatility of the industry, we conducted an additional search using Google and Yahoo to identify companies that directly offered genetic ancestry testing services to online consumers. The following key phrases related to genetic ancestry testing were searched: "genetic ancestry test," "genetic DNA test," "DNA ancestry test," "Y-chromosome testing," and "mtDNA testing." For the purpose of topical relevance, links on the first two pages of each search result were accessed and reviewed for information regarding companies that offered genetic ancestry testing services. The results ranged from webpages of ancestry testing companies to news pieces and consumer review reports. After accounting for repetition and overlap, 52 unique genetic ancestry testing companies were recorded for further analysis.

A comparison between our initial web search and the scholarly literature led to the identification of 73 unique genetic ancestry testing companies, 31 of which were uniquely contributed by our web search. Companies that met the following inclusion criteria were retained for further analysis: (1) have functional webpages in English, (2) currently selling a genetic ancestry test, (3) offer an ancestry test with a distinct category for Native American ancestry. For this category, accepted terms were "Native American," "indigenous American," "First Nations," "American Indian," "North American," and "Native Alaskan." A final list of 25 companies was retained for deeper content analysis.

We analyzed the textual content from the webpages of the 25 companies, including the main page and subpages that described ancestry testing services in greater detail. A qualitative content analysis of all text from these pages was conducted from 21 December 2017 to 15 January 2018. To capture the information consumers were most likely to see on an initial visit to the site, we limited ourselves to subpages up to two clicks away, which captured a majority of the relevant information on the website. We reviewed the webpages to identify language pertaining to personal identity, genetic ancestry, test precision, Native American ancestry, and tribal enrollment. To maintain consistency, one investigator completed all the coding while one other reviewed the coding scheme and held discussions to review any ambiguous or uncertain coding applications (Table 1).

\section{RESULTS}

Most company sites prominently feature a marketing slogan or tagline alluding to self-discovery, uncovering the past, or lauding the unique quality of the service. Prices range from $\$ 70$ to $\$ 300$ for each test. Some companies offer a stand-alone test for Native American ancestry, while others include it in a bundled testing package for other heritages or types of information (e.g., health). Images are integrated within textual details to enhance marketing messages, including symbols often associated with Native American culture and models with darker skin and features that echo stereotypical images of Native American individuals. ${ }^{25}$

All of the companies we examined test for Native American ancestry; however, there are differences in the terminology they employ to label this identity, as shown in Table 2. 
Table 1 Company names and websites

\begin{tabular}{|c|c|c|}
\hline & Company name & Website \\
\hline a. & Alpha Biolabs & http://www.alphabiolabs.co.uk/ \\
\hline b. & Ancestry.com & https://www.ancestry.com/dna/ \\
\hline c. & CRI Genetics & https://crigenetics.com \\
\hline$d$ & DNA Consultants & https://dnaconsultants.com/ \\
\hline e & DNA Diagnostic Center & https://dnacenter.com \\
\hline f & DNA Force Lab & https://dna-testing.ca \\
\hline g. & $\begin{array}{l}\text { DNA Reference } \\
\text { Laboratory }\end{array}$ & http://dnareferencelab.com \\
\hline h. & DNA Tribes & http://www.dnatribes.com/ \\
\hline i. & DNA Worldwide & https://www.dna-worldwide.com/ \\
\hline j. & Dynamic DNA & https://dynamicdnalabs.com/ \\
\hline k. & Easy DNA & https://www.easy-dna.com/ \\
\hline ।. & Family Tree DNA & https://www.familytreedna.com/ \\
\hline $\mathrm{m}$. & Genebase & https://www.genebase.com/ \\
\hline $\mathrm{n}$. & Gene2me & https://www.gene2me.global/en/ \\
\hline o. & Genetrack Biolabs & http://www.genetrackus.com/ \\
\hline p. & The Genealogist & https://www.thegenealogist.com/dna/ \\
\hline $\mathrm{q}$ & GTL DNA & https://www.gtldna.co.uk/ \\
\hline r. & $\begin{array}{l}\text { International } \\
\text { Biosciences }\end{array}$ & https://www.ibdna.com \\
\hline s. & HomeDNAdirect & https://www.homednadirect.com/ \\
\hline t. & Living DNA & https://www.livingdna.com/en-us \\
\hline u. & My Heritage & https://www.myheritage.com/dna \\
\hline v. & Roots For Real & https://www.rootsforreal.com/ \\
\hline w. & $\begin{array}{l}\text { The Genographic } \\
\text { Project }\end{array}$ & $\begin{array}{l}\text { https://genographic.nationalgeographic. } \\
\text { com/ }\end{array}$ \\
\hline $\mathrm{x}$. & Who'z The Daddy & https://www.whozthedaddy.com/ \\
\hline y. & 23andMe & https://www.23andme.com/ \\
\hline
\end{tabular}

Table 2 Company characterization of Native American ancestry

\begin{tabular}{ll} 
Characterization & Number of companies (out of 25) \\
\hline Native American & 16 \\
North American & 4 \\
\hline Indigenous North America & 2 \\
\hline Indigenous American & 2 \\
Native Indians \& First Nations & 1 \\
Cherokee & 1 \\
American Indian & 1 \\
\hline
\end{tabular}

Table 3 illustrates similarities and differences in how companies frame the purposes and limitations of their general ancestry services. Of 25 companies, 20 state that consumers will be able to discover their ancestral origins, which was the most consistent claim across all services. In terms of limitations, 13 companies acknowledge that their services
Table 3 Purposes and limitations of general ancestry test as described on company websites

\begin{tabular}{ll}
$\begin{array}{l}\text { Purposes and limitations of general } \\
\text { ancestry testing }\end{array}$ & $\begin{array}{l}\text { Number of companies } \\
\text { (out of 25) }\end{array}$ \\
\hline Purposes & 20 \\
\hline Determine ancestral origin & 8 \\
\hline Discover who you are & 5 \\
\hline Find new relatives & 2 \\
\hline Confirm culture and traditions & 13 \\
\hline Limitations & 3 \\
\hline Only an estimate of ancestral origins & \\
\hline $\begin{array}{l}\text { Does not establish race or group } \\
\text { membership }\end{array}$ &
\end{tabular}

reflect only an estimate of ancestral origins, and only 3 explicitly make the distinction between genetic ancestry and concepts of ethnicity and race. Conversely, as shown in Table 4, 11 companies suggest that the results of their ancestry test are definitive in their ability to pinpoint ancestry. Eight companies offer claims of both definitiveness and estimation: that their results are both an exact determination of ancestry and an estimation of likelihoods.

Five companies offer a test solely to determine the percentage of Native American heritage, while the other 20 incorporate it as a subcategory within a general ancestry test. Among the five companies, there is a gradient of claims regarding Native American identity as shown in Table 5, ranging from a confirmation of some historical claim to Native American ancestry to asserting legitimacy in a tribal enrollment process. Aside from asserting their ability to prove Native American ancestry, we found no discernible patterns or clusters of themes shared among companies making claims towards tribal enrollment. Only some companies explicitly acknowledge the limitations of their services in determining Native American identity.

\section{DISCUSSION}

The proliferation of DTC genetic ancestry companies raises questions about how these services operate and market tests to potential consumers. Native scholars and tribal communities have been openly critical of the use of genetic ancestry to define who is Native American and who is not, particularly as it reduces Native identity to a collection of biological determinants, superseding important cultural and historical considerations. $^{26}$ While scholars have debated the consequences in conflating genetic ancestry with racial, political, and ethnic identities, ${ }^{27,28}$ there has been little empirical research about these concerns as they relate to Native American identity. Our study findings help to bridge this gap and address how current company practices may affect tribal communities.

To frame how the 25 companies studied articulate Native American ancestry and identity, we first consider the more immediate promises companies make regarding the 
Table 4 Precision of test as described by company websites

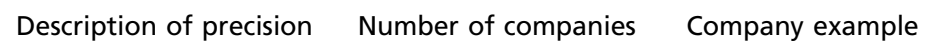

\begin{tabular}{lll}
\hline $\begin{array}{l}\text { Determine exact point of } \\
\text { origin }\end{array}$ & 11 & $\begin{array}{l}\text { "Yes, this highly accurate and cutting-edge ancestry test will tell you which countries on the } \\
\text { world map we know today your ancestors originated from" (s) }\end{array}$ \\
$\begin{array}{l}\text { Uncover your true ancestry } \\
\text { in DNA }\end{array}$ & 10 & "Begin discovering your true ancestral roots with this simple DNA test" (k) \\
$\begin{array}{l}\text { Use of objective, scientific } \\
\text { method of analysis }\end{array}$ & 5 & $\begin{array}{l}\text { "Company] analysis does not make any assumptions based on non-scientific racial divisions; } \\
\text { instead [it] defines world regions using objective mathematical criteria" (h) }\end{array}$ \\
\hline
\end{tabular}

Table 5 Purposes and limitations of Native American ancestry test as described on company websites

\begin{tabular}{ll}
$\begin{array}{l}\text { Purposes and limitations of Native } \\
\text { American testing }\end{array}$ & $\begin{array}{l}\text { Number of companies } \\
\text { (out of 5) }\end{array}$ \\
\hline Purposes & 5 \\
$\quad$ Prove Native American ancestry & 4 \\
$\quad \begin{array}{l}\text { Establish Native American cultural } \\
\text { affiliation }\end{array}$ & 2 \\
$\quad$ Assist with admission into a tribe \\
$\begin{array}{l}\text { Limitations } \\
\quad \text { Tribes set laws for tribal citizenship } \\
\quad \begin{array}{l}\text { Results not a substitute for legal } \\
\text { documentation }\end{array}\end{array}$ \\
\hline
\end{tabular}

interchangeability of ancestral and personal identity. While most companies promise to aid consumers in the discovery of their ancestral origins, many go one step further and allude to deeply personal impressions of individual identity through marketing slogans such as "Reinvent the way you see yourself" (c) and "Discover Yourself" (j). By invoking a personal sense of uncertainty and incompleteness with broad, open-ended questions such as "7 million people have learned more about themselves. Are you next?" (b) or "Who are you?" (c) and then immediately offering a remedy with a promise of selfdiscovery, companies engage in what anthropologist Sandra Soo-Jin Lee calls "meaning-making," or the act of offering "a consumer-driven process of discovery where individuals are presumed free to select genetic 'facts' to recreate one's life history." 12 This "choice," however, is already preinscribed in the language utilized by companies, which tells potential consumers that genetic ancestry test results will reinvent how they see themselves, regardless of the actual results or one's prior conception of identity. While this hyperbolic "it-willchange-your-life" marketing strategy is not unique to DTC genetic ancestry companies, it is distinct in the way it draws upon public faith in science and scientific authority to validate a causal relationship between genetic ancestry and personal identity. ${ }^{29}$ This meaning-making helps to contextualize seemingly dramatic interpretations of results by consumers who reimagine and then adjust significant aspects of their personal identities to incorporate genetic "facts" that are informed by test results. ${ }^{18,19,23,30}$
The manner in which companies frame their Native American ancestry testing services has sociopolitical implications for tribal communities. Companies employ a variety of terms to characterize Native American ancestry, and each phrase invokes different aspects of indigeneity. The term "North American" refers to a geographical locality, while "Indigenous North America" and "Indigenous American" appeal to a sense of original inhabitance within a region. The remaining terms, "Native American," "Native Indians and First Nations," "Cherokee," and "American Indian" draw on political and cultural identities that are specific to established tribal communities in the United States and Canada, appearing to evoke a degree of legitimacy and specificity that goes beyond geographical locality. The two companies that claim their results can assist with tribal admission used one of these four latter terms. These variations in terminology suggest that companies are trying to evoke particular tribal values or modes of identification in marketing tests to potential consumers.

The data further illustrate how companies make interchangeable claims regarding Native American ancestry and Native American identity. Companies equate a sense of historical heritage with current political identities, as demonstrated by the following examples: "Are you searching for your Native American roots? Do you want to find genealogy information on your Native American clan or nation?" (d), and "Are you Native American? Find out if you have Native American ancestry" (m). These examples demonstrate company claims in which the presence of Native American ancestry, as determined by a genetic test, also appears to confer current Native American identity.

This causal relationship between genetics and identity is propagated by the concept of "Native American DNA," or a series of genetic markers that can reveal Native American ancestry. Given that there is no discrete segment or set of segments that are found in everyone who identifies as Native American or is a current member of a tribe, the term "Native American DNA" is scientifically misleading. The genetic markers commonly used to identify this type of ancestry are also found in other populations at lower frequencies. ${ }^{31}$ While some companies in this study do acknowledge that ancestry test results are based on estimates, many also suggest that 
their tests are definitive, which obscures how consumers should understand the state of the science.

Company practices that reinforce the concept of "Native American DNA" create a misleading impression of the extent to which genetics can reliably comment on Native American heritage. Past instances in which genetic evidence was sought to legitimize Native American ancestry and identity illustrate the damaging consequences such efforts produce for individuals and communities. Prominent examples include the case of Kennewick Man, a figure who was determined to have lived 9000 years ago and whose remains were found in 1996 near the Columbia River in Washington State. Five tribes, the Yakama, Wanapum, Umatilla, Colville, and Nez Perce nations, cited Kennewick Man as an ancient ancestor and argued for the reburial of the remains, a right protected under the 1990 Native American Graves Protection and Repatriation Act (Pub. L. No. 101-601, 5237 H.R.). A group of scientists challenged this claim, demanding genetic analysis to "prove" Kennewick Man's Native American origins. Substantial DNA could not be extracted from the remains, and after a long legal battle, the US Army Corps of Engineers retained control over Kennewick Man, placing him in the Burke Museum at the University of Washington. In 2015, a team of geneticists from Stanford University and the University of Copenhagen analyzed bone fragments from the skeleton and determined that Kennewick Man was most closely related to "modern Native Americans" in the United States. ${ }^{32}$ Based on this new evidence, the Army Corps has agreed to return the remains to the five tribes so they can begin the long sought-after reburial ceremony. Anthropologist Kim TallBear describes Kennewick Man as a case in which, when both scientific and indigenous voices exist, "scientific activities are often granted exclusive jurisdiction over knowledge production," especially what qualifies as valid evidence in determining Native American identity. $^{29}$

Another case in which genetics was promised as a determinant of Native American identity is that of the Cherokee Freedmen, descendants of emancipated slaves who were granted full tribal citizenship in 1866 by the Cherokee Nation in Oklahoma. In 1983, however, the Cherokee Nation revised their enrollment criteria requiring members to carry certificates verifying that their ancestors were recorded on the 1906 Dawes Roll, a census document that excluded freed slaves. Despite ties with the tribal community and participation in cultural events, Freedmen were subsequently denied tribal membership. In 2004, geneticist Rick Kittles offered to assist the Freedmen's cause in reclaiming tribal identity by providing free DNA ancestry tests under the assumption that genetic information would be convincing evidence. The results of the tests were underwhelming, displaying an average of $6 \%$ Native American ancestry among tested Freedmen, a percent similarly reflected in other AfricanAmerican populations along the East coast. ${ }^{33}$ While these results do not mention error bars or the limitations of the technology, they nonetheless carry heavy symbolism for those looking for personal meaning and validation from genetic results. This case exemplifies the consequences of overstating the benefits of genetic ancestry testing in verifying cultural identity.

The cases of Kennewick Man and the Cherokee Freedmen illustrate how a genetic test for Native American ancestry raises questions around what legitimizes one's "indigeneity" or Native identity. Currently, tribes have sovereign power, as protected in the Constitution and other legal statutes, to determine the enrollment criteria in qualifying for tribal membership, which supersedes any genetic test for Native American ancestry, regardless of its scientific rigor. ${ }^{34}$ Providing evidence of familial connection is just one of many aspects that constitute Native identity; demonstrated community engagement and participation are also often key factors for tribal membership. ${ }^{35}$ The incongruence between the weight of genetic ancestry results as posited by commercial testing companies and the reality of tribal enrollment has led Native scholars to critically ask what non-Native people seek to justify and legitimize with the concept of "Native American DNA."29,31,36 This question emerges out of a complicated and tumultuous history between the United States and tribal nations, one characterized by the systematic interrogation of tribal legitimacy. Early federal removal acts sought to eradicate Native identity by forcibly dismantling tribal communities, seizing Native lands, and actively suppressing tribal languages and traditions through mandated assimilation. Later laws, which were framed as reparation efforts, granted official tribal status only to groups that met strict, federally mandated requirements. What ultimately emerged from this history was the recognition of the tribal right of sovereignty, which grants tribes the right to self-governance and self-determination. Marketing a genetic test for indigenous ancestry challenges this authority in claiming to determine who qualifies as Native American. Genetic ancestry testing companies are not subtle in how they view the relationship between Native identity and DNA, as illustrated in the use of phrases such as "Native American DNA" (d, f), "Indigenous DNA" (m), "DNA identity testing" (e), "Cherokee DNA" (d), and "First Nations Test" (f).

The unregulated promotion of DTC genetic ancestry tests for Native American identity potentially has wide-ranging consequences for tribal nations. The most immediate challenge is whether and how genetic ancestry tests will change how people identify in official contexts. Although companies persistently advertise genetic ancestry tests as a means for consumers to learn about and connect with diverse communities around the world, the perceived legitimacy of genetic ancestry results and the benefits associated with tribal identity may instead encourage more non-Native people to identify as American Indian/Alaskan Native on official forms such as the census and college and employment applications. ${ }^{37}$ On the federal level, the concept of "Native American DNA" raises concern around potential changes in federal requirements for benefit qualification. The requirement of blood quantum, or degree of Indian blood based on the number of Native American parents and grandparents one 
has, is one example of the power of the federal government to set benefit and enrollment qualifications. In 1934, after over a century of treaties attempting to eliminate tribes and tribal claims to land, the US Government passed the Indian Reorganization Act (IRA), which promised federal subsidies to tribes that adopted formal governing councils and constitutions. The act also required tribes to set enrollment criteria that included a minimum blood quantum for enrollees, a measurement that appeared as early as the General Allotment Act of 1887 to measure one's "nativeness" for land distribution. ${ }^{38,39}$ This numerical identity would be codified on an official document (e.g., a Certificate of Degree of Indian Blood) required to access federal benefits. With the increased use of genetics to establish ancestry, there is a concern that genetic testing may be introduced as an additional requirement to justify federal funding or a means to substantiate blood quantum via ancestry percentages. This concern is validated by a recent lawsuit in Washington State involving a man who tried to apply for a Disadvantaged Business Enterprise program, claiming minority status based on the $6 \%$ Native American and 4\% Sub-Saharan African results he received from a genetic ancestry test. After being denied entry into the program, he sued the Office of Minority and Women's Business Enterprises for its flawed racial categorizations. His case, Orion Insurance Group v. OMWBE, will be heard in the US District Court (Western District, Tacoma, Washington) in December 2018 and will be one of the first court cases in which a genetic ancestry test is being used as legal evidence. This demonstrates a concerning perception among consumers and policymakers that genetic ancestry tests qualify as "evidence" for proving one's identity or membership into a cultural group, a concern that is also raised by some of the discourse surrounding Senator Elizabeth Warren's decision to pursue genetic testing to prove her family's Native American ancestry in response to political pressure. $^{23}$

There are several limitations of this study. Due to the rapidly expanding nature of the industry, the status of many companies remains in flux. Since Wagner et al.'s study in 2012, six companies have gone out of business or have been absorbed by others. The instability of these companies may suggest instability of our data, and we acknowledge this as a risk of conducting a cross-sectional study of a volatile industry. To minimize this effect, we have updated our findings to capture any changes to the companies since we first collected data. Another limitation of our methodology is our analysis of only public-facing company sites, which limited our access to information provided to consumers after they purchased an ancestry test. However, this was not needed to fulfill the aims of our study, which were to assess how companies market their products to all potential consumers who visit the page, regardless of whether they ultimately purchase the product. A related limitation of this study is our inability to assess how company language around identity and Native American ancestry actually influences consumer behavior and self-identification. Are companies changing consumer behavior, or are consumers already coming in with certain expectations of verifying tribal ancestry and using the results as a means to accomplish this goal? Again, while these are important questions, they are beyond the scope of this study, which is to describe the state of the industry. An indepth look at how individuals may understand and interpret genetic ancestry results in relation to their current identities can be found within the work of Wendy Roth and colleagues. $^{19,37,40}$

There are many distinctive and consequential ways DTC genetic ancestry companies frame and invoke Native American identity when marketing their products to potential consumers. In an effort to mitigate these negative effects, scholars have proposed placing accountability on genetic ancestry companies to ensure they accurately convey the limitations of their tests, identify genetic ancestry categories that reflect the state of the science and avoid political and cultural identities, and perhaps, as suggested by Lee et al., use a standard taxonomy of genetic ancestry concepts when discussing test results to make it clear to users what information they are actually receiving and how best to interpret findings. Based on our findings, we recommend that companies demonstrate more consistent practices when portraying the appropriate limits of their tests. For example, companies should have a clear, accessible description of how to interpret the science behind the test, rather than offering contradictory statements that describe genetic ancestry results as both definitive measurements and broad estimations. Similarly, companies should offer clear statements that distinguish between genetic ancestry results and concepts of race, ethnicity, and group membership. For companies seeking to diversify and expand their databases, we recommend that they do so in tandem with genuine efforts to engage the communities from which they collect information, which in turn may help companies develop more appropriate ancestry and marketing language.

We hope this overview of DTC genetic ancestry companies provides a starting point for further research that is needed to investigate the consequences of commercial genetic technologies for US tribal communities and to explore the obligations of different stakeholders in creating a more ethically responsible industry.

\section{ELECTRONIC SUPPLEMENTARY MATERIAL}

The online version of this article (https://doi.org/10.1038/s41436018-0429-2) contains supplementary material, which is available to authorized users.

\section{ACKNOWLEDGEMENTS}

The authors thank Vence Bonham, Edmund Keane, and Benjamin E. Berkman for valuable discussion and feedback on earlier drafts of this article. The views expressed are the authors' own. They do not represent the position or policy of the National Institutes of Health or the Department of Health and Human Services. 


\section{DISCLOSURE}

The authors declare no conflicts of interest.

Publisher's note: Springer Nature remains neutral with regard to jurisdictional claims in published maps and institutional affiliations.

\section{REFERENCES}

1. O'Brien SA. 23andMe wants to develop drugs based on your DNA. CNNMoney. 12 September 2017. http://money.cnn.com/2017/09/12/ technology/23andme-250-million/index.html. Accessed 8 February 2018.

2. Anders M. DNA ancestry test kits are hot holiday gifts despite privacy concerns from some. Forbes. https://www.forbes.com/sites/ melissaanders/2017/12/06/dna-ancestry-test-kits-are-hot-holiday-giftsdespite-privacy-concerns-from-some/. Accessed 5 February 2018.

3. Gill L. Genetic tests to find ancestry could allow companies to exploit you, Schumer warns. Newsweek. 27 November 2017. http://www. newsweek. com/genetic-tests-find-ancestry-could-allow-companies-exploit-youschumer-warns-723091. Accessed 8 February 2018.

4. Bolnick DA, Fullwiley $D$, Duster $T$, et al. The science and business of genetic ancestry testing. Science. 2007;318:399-400.

5. Royal CD, Novembre J, Fullerton SM, et al. Inferring genetic ancestry: opportunities, challenges, and implications. Am J Hum Genet. 2010; 86:661-673

6. Jobling MA, Rasteiro R, Wetton JH. In the blood: the myth and reality of genetic markers of identity. Ethn Racial Stud. 2016:39:142-161.

7. Lee SS-J, Bolnick DA, Duster T, Ossorio P, TallBear K. The illusive gold standard in genetic ancestry testing. Science. 2009;325:38-39.

8. Gutmann A, Wagner JW, Ali Y, Allen AL, Arras JD. Privacy and progress in whole genome sequencing. Washington, DC: Presidential Commission for the Study of Bioethical Issues; 2012.

9. Kolata G, Murphy H. The Golden State Killer is tracked through a thicket of DNA, and experts shudder. The New York Times. 27 April 2018. https://www.nytimes.com/2018/04/27/health/dna-privacy-golden-statekiller-genealogy.html. Accessed 30 April 2018.

10. Phillips AM. Only a click away-DTC genetics for ancestry, health, love.. and more: a view of the business and regulatory landscape. Appl Transl Genom. 2016;8 (suppl C):16-22.

11. Sarata A. Genetic ancestry testing: CRS report for Congress. https://www. everycrsreport.com/reports/RS22830.html. Accessed 4 January 2018.

12. Lee SS-J. Race, risk, and recreation in personal genomics: the limits of play. Med Anthropol Q. 2013;27:550-569.

13. Sankar $P$, Cho MK, Mountain J. Race and ethnicity in genetic research. Am J Med Genet A. 2007:143:961-970.

14. Shriver MD, Kittles RA. Genetic ancestry and the search for personalized genetic histories. Nat Rev Genet. 2004;5:611.

15. Elliott C, Brodwin P. Identity and genetic ancestry tracing. BMJ. 2002;325:1469-1471.

16. Nelson A. The social life of DNA: race, reparations, and reconciliation after the genome. Boston: Beacon Press; 2016.

17. Hochschild JL, Sen M. To test or not? Singular or multiple heritage?: genomic ancestry testing and Americans' racial identity. Du Bois Rev. 2015; 12:321-347.

18. Heine SJ. DNA is not destiny: the remarkable, completely misunderstood relationship between you and your genes. 1st ed. New York: W. W. Norton \& Company; 2017.

19. Roth WD, Ivemark B. Genetic options: the impact of genetic ancestry testing on consumers' racial and ethnic identities. Am J Sociol. 2018;124:150-184.

20. Pullman D, Arbour L. Genetic research and culture: where does the offense lie?. In: Youngessor JO, Brunkessor CG, (eds.) The ethics of cultural appropriation. p. 115-139. Wiley-Blackwell; 2009.
21. TallBear K. The Weyanoke Association: DNA \& Indian ancestry. http:// www.weyanoke.org/historyculture/hc-DNAandlndianAncestry.html. Accessed 15 November 2017

22. Garrison NA. Genomic justice for Native Americans: impact of the Havasupai case on genetic research. Sci Technol Human Values. 2013;38:201-223.

23. Raff J. What do Elizabeth Warren's DNA test results actually mean? Forbes. https://www.forbes.com/sites/jenniferraff/2018/10/15/what-doelizabeth-warrens-dna-test-results-actually-mean/. Accessed 22 October 2018.

24. Wagner JK, Cooper JD, Sterling R, Royal CD. Tilting at windmills no longer: a data-driven discussion of DTC DNA ancestry tests. Genet Med. 2012; $14: 586$

25. Weaver HN. What color is red? Exploring the implications of phenotype for Native Americans. In: Hall RE (ed.) The melanin millennium. p. 287-299. Dordrecht, The Netherlands: Springer; 2013.

26. Bardill J. Tribal enrollment and genetic testing. http://genetics.ncai.org/ tribal-enrollment-and-genetic-testing.cfm. Accessed 16 November 2017.

27. Reich D. How to talk about 'race' and genetics. The New York Times. 30 March 2018. https://www.nytimes.com/2018/03/30/opinion/racegenetics.html. Accessed 1 May 2018.

28. Kahn J. How not to talk about race and genetics. BuzzFeed. 20 March 2018. https://www.buzzfeed.com/bfopinion/race-genetics-david-reich. Accessed 1 May 2018.

29. TallBear K. Genomic articulations of indigeneity. Soc Stud Sci. 2013; 43:509-533.

30. Bahrampour T. They considered themselves white, but DNA tests told a more complex story. Washington Post. 6 February 2018. https://www. washingtonpost.com/local/social-issues/they-considered-themselveswhite-but-dna-tests-told-a-more-complex-story/2018/02/06/16215d1ae181-11e7-8679-a9728984779c_story.html. Accessed 8 March 2018.

31. TallBear K, Bolnick DA. "Native American DNA" tests: what are the risks to tribes? Study cites further undermining of tribal sovereignty. The Native Voice. 2004

32. Rasmussen $M$, Sikora $M$, Albrechtsen $A$, et al. The ancestry and affiliations of Kennewick Man. Nature. 2015:523:455-458.

33. Koerner BI. Blood feud. Wired. https://www.wired.com/2005/09/ seminoles/. Accessed 1 February 2018.

34. Obama B. Presidential memorandum on tribal consultation. 5 November 2009. https://obamawhitehouse.archives.gov/the-press-office/memorandumtribal-consultation-signed-president

35. TallBear K. Native American DNA: tribal belonging and the false promise of genetic science. University of Minnesota Press; 2013.

36. Reardon J, TallBear K. "Your DNA is our history": genomics, anthropology, and the construction of whiteness as property. Curr Anthropol. 2012;53 (suppl 5):S233-S245.

37. Golbeck N, Roth W. Aboriginal claims: DNA ancestry testing and changing concepts of indigeneity. In: Berthier-Foglar S, CollingwoodWhittick S, Tolazzi S, (eds.) Biomapping indigenous peoples: towards an understanding of the issues. p. 415-432. Amsterdam, Netherlands: Rodopi; 2012.

38. TallBear K. Native-American-DNA.com: in search of Native American race and tribe. In: Koenig BA, Lee SS-J, Richardson SS, (eds.) Revisiting race in a genomic age. p. 235-252. New Brunswick, NJ: Rutgers University Press; 2008.

39. Schmidt RW. American Indian identity and blood quantum in the 21st century: a critical review. J Anthropol. 2011;2011:1-9.

40. Roth W, Lyon K. Genetic ancestry tests and race: who takes them, why, and how do they affect racial identities? In: Suzuki K, Vacano DV, (eds.) p. 133-170. Reconsidering Race: Social Science Perspectives on Racial Categories in the Age of Genomics. New York: Oxford University Press; 2018. 